Diabetologia 8, 19-28 (1972)

(c) by Springer-Verlag 1972

\title{
Enzymehistochemical Studies on the Pancreatic Islets in Mice Injected with Anti-Insulin Serum*
}

\author{
G. KIöppel, G. Freytag and G. Bommer \\ Department of Pathology of the University Hamburg, Germany
}

Received: August 26, 1971, accepted: November 26, 1971

\begin{abstract}
Summary. Islets of Langerhans in white mice with a diabetic syndrome after single and repeated injections of anti-insulin serum were studied by enzymehistochemical methods and compared with controls. Changes in activity of some enzymes were noted in the islet area in accordance with the histopathological findings of severe degranulation and hypersecretory changes of the beta cells. - The $\alpha$-glycerophosphate oxidase (GPOX) showed the most sensitive and severe decrease of activity whereas the acid phosphatase (ACPase) was only slightly decreased. Compared with the enzyme activity in normal mice, no significant changes of glucose-6-phosphate dehydrogenase (G-6-PD) could be observed. The only enzyme showing an increased activity was the glucose-6-phosphatase (G-6-Pase). The studies of the cytochrome oxidase (CCOX), lactic dehydrogenase (LDH), succinic dehydrogenase (SDH), acid phosphatase (ACPase), alkaline phosphatase (APase) and adenosine triphosphatase (ATPase) revealed no alterations of the enzyme patterns under these experimental conditions. The findings are discussed with regard to the hypothetical relations between the pentose phosphate shunt (indicator enzyme: G-6-PD), the glycerophosphate cycle (indicator enzyme: GPOX) and the phosphorylation of glucose (indicator enzyme: G-6Pase) to insulin synthesis and release.
\end{abstract}

L'examen histochimique enzymatique d'ôlots de Langerhans après injection de sérum anti-insuline

Résumé. On a procédé à l'examen histochimique enzymatique d'îlots de Langerhans sur des souris ayant un syndrome diabétique après injection unique, ou répétée, de sérum anti-insuline, et on les a comparés avec des résultats normaux. Les variations de l'activité des en zymes des cellules-B se sont trouvées en accord avec les résultats histopathologiques de dégranulation importante et de variations hypersécrétoires des cellules-B. L'a-glycérophosphate-oxydase (GPOX) a móntré la diminution d'activité la plus sensible et la plus forte. Par contre la diminution de l'activité de la phosphatase acide (ACPase) était moins forte. La glucose-6-phosphatedéshydrogénase (G-6-P-DH) a accusé une activité de même intensité que dans un cas normal. La glucose-6phosphatase (G-6-Pase) fut le seul enzyme à faire preuve d'une accroissement d'activité. Les activités de la cyto- chrome-oxydase (CCOX), de la lactico-déshydrogénase (LDH), de la succino-déshydrogénase (SDH), de la phosphatase alcaline (AP), ainsi que de l'adénosine-triphosphatase (ATPase) sont restées sans changement. - Le rôle du cycle du pentose phosphate (enzyme indicateur: G-6-P-DH), du cycle du glycérophosphate (enzyme indicateur: GPOX) et de la phosphorylation du glucose (enzyme indicateur G-6-Pase) est discuté en ce qui concerne le mécanisme de synthèse et de libération de l'insuline.

Enzymhistochemische Untersuchungen am Inselorgan der Maus nach Injektion von Anti-Insulin-Serum

Zusammenfassung. Es wurden enzymhistochemische Untersuchungen an den Langerhansschen Inseln von Mäusen mit einem diabetischen Syndrom nach einmaliger und wiederholter Injektion von Anti-Insulin-Serum durchgeführt und mit Normalbefunden verglichen. Analog zu den pathohistologischen Befunden einer starken Degranulierung und hypersekretorischer Alterationen der B-Zellen fanden sich Aktivitätssteigerungen bei einigen Enzymen im Bereich der Inseln. - Die empfindlichste und stärkste Aktivitätsminderung ließ die $\alpha$-Glycerophosphatase(GPOX) erkennen. Weniger stark war die Aktivitätsabnahme der sauren Phosphatase (SP). Eine gleichstarke Aktivität wie im Normalfall wies die Glucose-6-Phosphat Dehydrogenase (G-6-P-DH) auf. Als einziges Enzym zeigte die Glucose-6-Phosphatase (G-6-Pase) eine Aktivitätssteigerung. Die Aktivität der Cytochromoxydase (CCOX), Lactat-Dehydrogenase (LDH), Succino-Dehydrogenase (SDH), alkalischen Phosphatase (AP) und Adenosintriphosphatase (ATPase) blieb unverändert. Die Befunde werden im Zusammenhang mit den hypothetischen Beziehungen des Pentosephosphateyclus (Indikatorenzym: G-6-P-DH), des Glycerophosphatcyclus (Indikatorenzym: GPOX) und der Glucosephosphorylierung (Indikatorenzym: G-6-Pase) zur Insulinsynthese und -sekretion diskutiert.

Key words: Mouse pancreatic islets, $\beta$-cells, stimulation anti-insulin serum, diabetic syndrome, enzymehistochemical studies, $\alpha$-glycerophosphate oxydase, acid phosphatase, glucose-6-phosphate dehydrogenase, glucose-6phosphatase.
The behaviour of the enzyme activities in the pancreatic islets in physiological and pathological conditions gives some information about the main metabolic pathways in the beta cells. Enzymehistochemical findings have revealed a different enzyme pattern of the exocrine and endocrine parts of the pancreas, as well as demonstrating enzymes with a high activity

* Supported by Deutsche Forschungsgemeinschaft, Bad Godesberg, Germany. within the islets of many species $[14,41]$. Thus Lazarus [24] and Lazarus and Bradshaw [28] referred to the importance of glucose-6-phosphatase and glucose-6phosphate dehydrogenase, with regard to insulin synthesis and secretion. Gössner [13] drew attention to the activity of the $\alpha$-glycerophosphate oxidase in the islet tissue. The importance of the acid phosphatase is often discussed in relation to protein synthesis since acid phosphatase has been demonstrated in many 
cells having a secretory function, particularly in the islet cells of some species $[48,20,21,50]$.

Besides the histochemical studies in nondiabetic animals, systematic investigations have been performed in animals with a spontaneous diabetic syndrome, as in obese-hyperglycaemic mice $[16,17], \mathrm{kk}$-mice [38] and rats with an experimental congenital diabetes [50]. Further enzymehistochemical findings have been reported after alloxan, cortisone and growth hormone injections as well as application of sulphonylureas [25, $26,11]$.

In order to get further information concerning changes in enzyme activity after heavy stimulation of the insulin releasing process, mice have been made hyperglycaemic by injections of anti-insulin serum $[35,9]$. Special reference is made to the pathophysiological significance of the different enzyme patterns in the islets under these conditions and their possible involvement in the mechanism of insulin synthesis and release.
The pancreas was frozen immediately after removal in dry ice and kept at $-45^{\circ} \mathrm{C}$. Frozen sections, $6 \mu$ thick, were cut in a cryostat maintained at $-20^{\circ} \mathrm{C}$ and fixed to cover slips. They were dried $10 \mathrm{~min}$ at room temperature before incubation. This was necessary to avoid damage of the tissue by abrupt change of temperature between the cryostat and the incubator.

The intensity of the enzyme reactions were judged using light microscopy (explanation see Table 1) and compared with control sections (a) of normal mice and (b) of mice injected with normal guinea pig serum. These sections were always incubated under equal conditions. Alternate sections were stained with haemalum-eosin and periodic acid Schiff (PAS) in order to correlate the morphological and the enzymehistochemical changes.

The following incubation media were used:

A) Succinic dehydrogenase (SDH): [28] $2 \mathrm{ml} 0.1 \mathrm{M}$ phosphate buffer with KCN $(2 \mathrm{mg} \%) \mathrm{pH} 7.6 ; 2 \mathrm{ml}$ Nitro B-T (3 mg/ml); $0.6 \mathrm{ml} 0.05 \mathrm{M} \mathrm{MgCl} \mathrm{M}_{2} ; 2 \mathrm{ml}$

Table 1. Changes of enzyme activities in the pancreatic islets of mice injected with insulin antibodies

\begin{tabular}{|c|c|c|c|c|c|c|c|c|c|c|}
\hline Serum & Titre & GPOX & G-6-PD & G-6-Pase & ACPase & APase & ATPase & CCOX & SDH LDH & Time \\
\hline $\begin{array}{l}\text { Controls } \\
\text { GPAIS } \\
\text { GPAIS } \\
\text { GPAIS } \\
\text { GPAIS } \\
\text { GPAIS }\end{array}$ & $\begin{array}{l}<10 \\
<10 \\
<10 \\
<5 \\
<10\end{array}$ & $\begin{array}{r}+++ \\
++ \\
++ \\
++ \\
++ \\
+\end{array}$ & $\begin{array}{l}++ \\
++ \\
++ \\
++ \\
+ \\
++\end{array}$ & $\begin{array}{l}+++ \\
+++\end{array}$ & $\begin{array}{l}++ \\
++ \\
++ \\
++ \\
+ \\
+\end{array}$ & $\begin{array}{l}(+) \\
(+) \\
(+) \\
(+) \\
(+) \\
(+)\end{array}$ & $\begin{array}{l}(+) \\
(+) \\
(+) \\
(+) \\
(+) \\
(+)\end{array}$ & $\begin{array}{l}+ \\
+ \\
+ \\
+ \\
+ \\
+\end{array}$ & $\begin{array}{ll}(+) & (+) \\
(+) & (+) \\
(+) & (+) \\
(+) & (+) \\
(+) & (+) \\
(+) & (+)\end{array}$ & $\begin{array}{l}\overline{1.5 \mathrm{~h}} \\
3 \mathrm{~h} \\
6 \mathrm{~h} \\
7 \mathrm{~d} \\
7 \mathrm{~d}\end{array}$ \\
\hline
\end{tabular}

Stronger activity of the endocrine tissue.

Stronger activity of the exocrine tissue.

\section{Materials and Methods}

Guinea pigs were immunized with crystalline beef insulin (Hoechst) and Freund's adjuvant throughout a period of $9-12$ weeks [10]. Animals were bled by cardiopuncture and the sera were frozen at $\div 20^{\circ} \mathrm{C}$. The titres of the insulin antibodies were estimated semiquantitatively by an electroprecipitin method, in order to separate them in pools with a low (5U) and a high (10U) insulin binding capacity. Two groups of 20 inbred Wistar mice $(25-30 \mathrm{~g} /$ body weight) were used. The animals of the first group received a single intravenous injection of high titre guinea pig antiinsulin serum (GPAIS) $(0.02 \mathrm{ml} / \mathrm{g}$ body weight). They were killed 1.5, 3 or $6 \mathrm{~h}$ later. Throughout a period of seven days, 10 animals of the second group were injected daily with a low and 10 with a high titre antiserum $(0.03 \mathrm{ml} / \mathrm{g}$ body weight). They were killed $1.5 \mathrm{~h}$ after the last injection.

Blood glucose was determined daily in six nonfasting animals before and $2 \mathrm{~h}$ after every injection. Blood samples were obtained by puncture of the orbital vein plexus and the blood glucose was measured by the glucose oxidase method (Boehringer, Mannheim).

$$
\begin{gathered}
++++ \text { very strong activity } \\
+++ \text { strong activity } \\
++ \text { moderately strong activity } \\
+ \text { slight activity } \\
(+) \text { very slight activity }
\end{gathered}
$$

$0.5 \mathrm{M}$ sodium succinate (Boehringer, Mannheim); $1.2 \mathrm{ml} \mathrm{NAD}(50 \mathrm{mg} / \mathrm{ml})$.

B) Lactic dehydrogenase (LDH): [19] $0.1 \mathrm{ml} 1 \mathrm{M}$ sodium lactate (Roth); $0.1 \mathrm{ml} 0.1 \mathrm{M}$ NAD; $0.1 \mathrm{ml}$ $0.1 \mathrm{M} \mathrm{KCN} ; 0.1 \mathrm{ml} 0.05 \mathrm{M} \mathrm{MgCl} ; 0.1 \mathrm{ml}$ a.d.; $0.25 \mathrm{ml}$ $0.2 \mathrm{M}$ Tris buffer pH $6.8 ; 0.25 \mathrm{ml}$ Nitro B-T $(1 \mathrm{mg} / \mathrm{ml})$ and $75 \mathrm{mg}$ polivinylpyrolidone (PVP).

C) Adenosine triphosphatase (ATPase): [49] $20 \mathrm{ml}$ $1.25 \mathrm{mg} \%$ ATP (Boehringer, Mannheim); $20 \mathrm{ml} 0.2 \mathrm{M}$ Tris-HCl buffer $\mathrm{pH} \quad 7.2 ; 3 \mathrm{ml} 2 \% \mathrm{~Pb}\left(\mathrm{NO}_{3}\right)_{2} ; 5 \mathrm{ml}$ $0.1 \mathrm{M} \mathrm{MgSO}_{4} ; 2 \mathrm{ml}$ a.d.; saturated solution $\mathrm{pH} 7.2$ with Tris-HCl buffer.

D) Alkaline phosphatase (AP): [39] $20 \mathrm{mg}$ sodiuma-naphthylphosphate (Serva); $40 \mathrm{ml} 0.1 \mathrm{M}$ Tris-HCl buffer pH $9.2 ; 40 \mathrm{mg}$ "Brentamin" fast red TR (Nordwald, Hamburg).

E) Acid phosphatase (ACPase): [4] $1.6 \mathrm{ml}$ pararosanilin hydrochloride; $1.6 \mathrm{ml} 4 \%$ sodium nitrite; after $60 \mathrm{sec} 8 \mathrm{ml}$ a.d. and $8.8 \mathrm{ml}$ Michaelis veronal acetate buffer stock solution, then $40 \mathrm{mg}$ sodium- $\alpha$ naphthylphosphate and $10 \mathrm{ml}$ Michaelis buffer stock solution.

F) Cytochrome oxidase (CCOX): [6] $0.5 \mathrm{ml} \mathrm{96 \%}$ ethanol; $10 \mathrm{mg} \propto$-naphtol AS (Fluka); $10 \mathrm{mg}$ 4-amino- 
diphenylamine; $35 \mathrm{ml}$ a.d.; $14.5 \mathrm{ml} 0.2 \mathrm{M}$ Tris- $\mathrm{HCl}$ buffer $\mathrm{pH}$ 7.4; sections are incubated then in $10 \%$ $\mathrm{Co}\left(\mathrm{NO}_{3}\right)_{2}$.

G) $\alpha$-Glycerophosphate oxidase (GPOX): [19] $7 \mathrm{ml}$ Ringer's solution; $7 \mathrm{ml} 0.35 \% \mathrm{KCN}$ in $0.2 \mathrm{M}$ phosphate buffer $\mathrm{pH} 7.2 ; 7 \mathrm{ml} 0.2 \mathrm{M}$ sodium- $\alpha$-glycerophosphate (Serva); $1 \mathrm{mg} 0.05 \mathrm{M} \mathrm{MgCl}_{2} ; 10 \mathrm{mg}$ NAD. The following solution is added: $4 \mathrm{ml}$ a.d., $15 \mathrm{mg}$ Nitro B-T in $3 \mathrm{ml}$ dimethyl formamide, a spatula tip of menadion [13].

H) Glucose-6-phosphate dehydrogenase (G-6-PD): [43] $5 \mathrm{ml} \mathrm{0.2} \mathrm{M} \mathrm{Tris-HCl} \mathrm{buffer} \mathrm{pH} 7.4 ; 15 \mathrm{mg}$ glucose6-phosphate (Serva); $16 \mathrm{mg}$ NADP; $1 \mathrm{mg}$ ethylenediamine tetraacetic acid (EDTA, Serva); $1.5 \mathrm{mg}$ tetranitro blue tetrazolium chloride (TNBT, Serva).

I) Glucose-6-phosphatase (G-6-Pase): [24] $5 \mathrm{ml}$ $0.02 \mathrm{M}$ glucose-6-phosphate; $5 \mathrm{ml} 0.15 \mathrm{M}$ Tris buffer; $0.75 \mathrm{ml} \mathrm{2} \%$ lead nitrate; $1.75 \mathrm{ml}$ a.d.; $1 \mathrm{ml} 0.002 \mathrm{M}$ tartaric acid is added; incubation $40 \mathrm{~min}$ at $32^{\circ} \mathrm{C}$; after rinsing sections are treated with $1 \%$ ammonium sulphide.

\section{Results}

The increase of blood glucose concentrations (see Table 2) and the histopathological changes of the islets after injection of guinea pig anti-insulin serum (GPAIS)

Table 2. Blood glucose levels in mice before and $2 \mathrm{~h}$ after injection of high (-) and low (- -) titre GPAIS 10.03

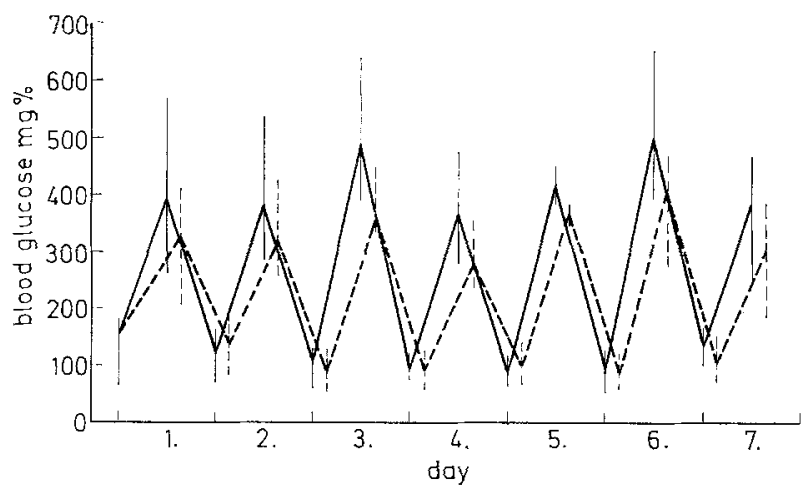

depended on the level of the insulin antibody titre (see Fig. $1 \mathrm{a}$ and $b$ ). However, the histochemical judgement of the islets after a single injection showed that changes in the enzyme activities were only seen after administration of high titre GPAIS. Therefore only high titre serum was used in the short term experiment.

Succinic dehydrogenase (SDH): In the controls, the islets showed very slight activity compared with the exocrine portions of the pancreas. The distribution in the islets was uniform. It was impossible to distinguish between alpha and beta cells. The activity remained unchanged in the animals with a diabetic syndrome.

Lactic dehydrogenase (LDH): In general the same findings were noted as described above.
Adenosine triphosphatase (ATPase): In the controls, the ATPase was localized in the endothelial cells of the capillaries and the small vessels as well as in the basal portion of the acinar cells. The islets showed a very slight activity. Treated animals showed no changes in ATPase activity. Depending on the peri- and intra-insular inflammatory infiltration there was a marked staining by ATPase in the swollen endothelial cells of the islet sinusoids.

Alkaline phosphatase (APase): In controls, the alpha cells at the islet periphery as well as the endothelial cells of the small vessels showed a moderately strong actitity. No changes could be noted in the treated animals.

Acid phosphatase (ACPase): In the controls, the islets showed moderately strong activity and differed only slightly in staining. The acinar and ductular cells showed less marked activity. No changes could be noted after a single injection. A slight decrease, however, was caused by repeated injections so that the staining of the islets was hard to distinguish from the adjacent tissue. At this time marked activity was noted in the inflammatory cells.

Cytochrome oxidase (CCOX): In controls and in treated animals, the endocrine and exocrine portions of the pancreas showed always very slight activity.

$\alpha$-Glycerophosphate oxidase (GPOX): In the controls, the islet cells showed a strong activity contrasting well with a considerably less activity in the exocrine tissue (see Fig. 2a). The intense reaction, however, did not distinguish between the different islet cell types. The first decrease in activity was seen 1.5 to $3 \mathrm{~h}$ after a single injection (see Fig. $2 \mathrm{~b}$ ). The treatment of seven days led to a further loss of activity in the islets, with the result that the staining could hardly be distinguished from the surrounding acinar cells (see Fig. $3 a$ and $b$ ).

Glucose-6-phosphate dehydrogenase (G-6-PD): In the controls, the islet cells showed moderately strong activity, contrasting well with the surroundings (see Fig. 4a). Although a differentiation between alpha and beta cells was impossible the uniform staining in controls and later in treated animals implied that beta cells were predominantly stained. No changes in activity were noted after single and even after repeated. daily injections of high titre GPAIS (see Fig. 4 c), whereas a slight decrease in activity could be observed after daily administration of low titre GPAIS (see Fig. 4b).

Glucose-6-phosphatase (G-6-Pase): In the controls, the islet cells showed strong activity, contrasting well with the surrounding exocrine tissue (see Fig. 5a). The stained islet cells were supposed to be beta cells by localization. The activity maintained unchanged after a single injection. After repeated injections of high titre GPAIS, very strong activity was observed (see Fig. 5c) whereas the injection of low titre GPAIS resulted in increase of activity only in a few beta cells (see Fig. 5b). The islets then looked somewhat spotted. 


\section{Discussion}

The single and repeated injections of guinea pig anti-insulin serum (GPAIS) result in a temporary hyperglycaemia, accompanied morphologically by a subtotal degranulation of the beta cells and later by
After stopping the administration of GPAIS, the diabetic syndrome vanishes in five to eight hours.

The bistochemical results in the controls corresponded well with the findings of other authors [14, 41]. After administration of GPAIS there were changes in the enzyme patterns of GPOX, ACPase, G-6-Pase
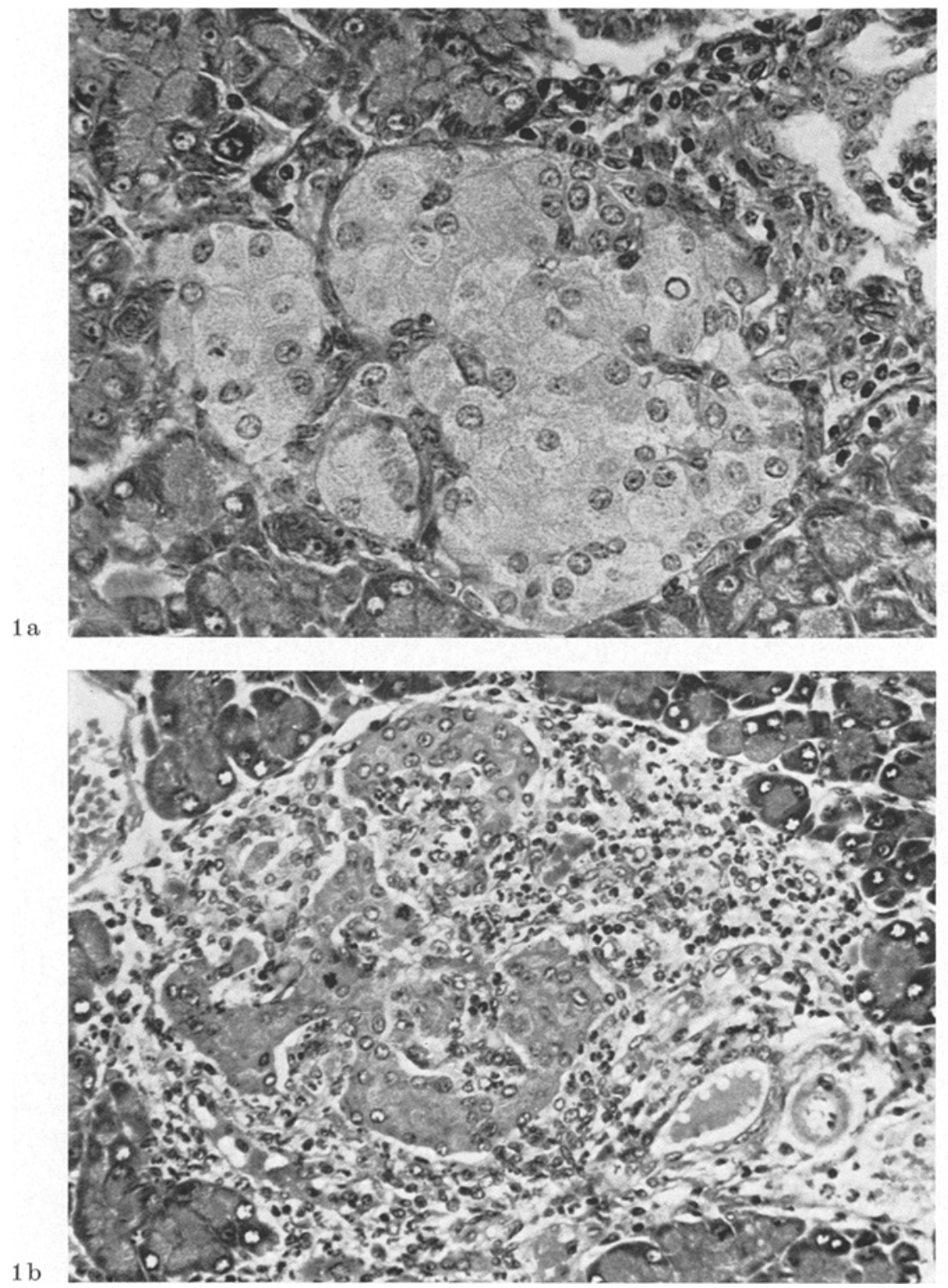

Fig. 1. Islet of mouse injected with (a) low and (b) high titre GPAIS for seven days. a) Some hypertrophic beta cells. Slight polymorphnuclear peri-insular infiltration. PAS X 500. b) Hypertrophy and nuclear polymorphism of the remaining beta cells. Extensive polymorphcellular peri- and intra-insular infiltration. PAS X 300

hyperplasia and neogenesis of the islets of Langerhans $[31,10]$. Together with the histological evidence of increased cellular activity a so called insulitis develops. Since both changes of the islets are due to an immune reaction between insulin and its precipitating antibodies, the degree of the insulitis and the hyperglycaemia depend on the level of the GPAIS titre [22]. and partly for G-6-PD whereas no changes occured in APase, ATPase, SDH, LDH and CCOX activities.

The first enzyme, discussed in particular, has to be the GPOX since there is already an early decrease after anti-insulin serum injection and a nearly complete disappearance of activity in the long term study. The GPOX which is localized in the mitochondrial mem- 
brane is involved in the NADH transferring system of the glycerophosphate cycle. Since NADH is mainly provided by glycolysis, a reduction of the glycolytic process after glucose-mediated insulin release, for example in favour of an active pentose phosphate shunt, may account for the early decrease of GPOX phosphate pathway is the provision of NADPH for biosynthetic processes. Evidence for the importance of this metabolic cycle within the beta cells is provided by the high activity of its enzymes, for example by the G-6-PD activity $[28,29,3]$, and the constant rise of some of its substrates after stimulation of insulin
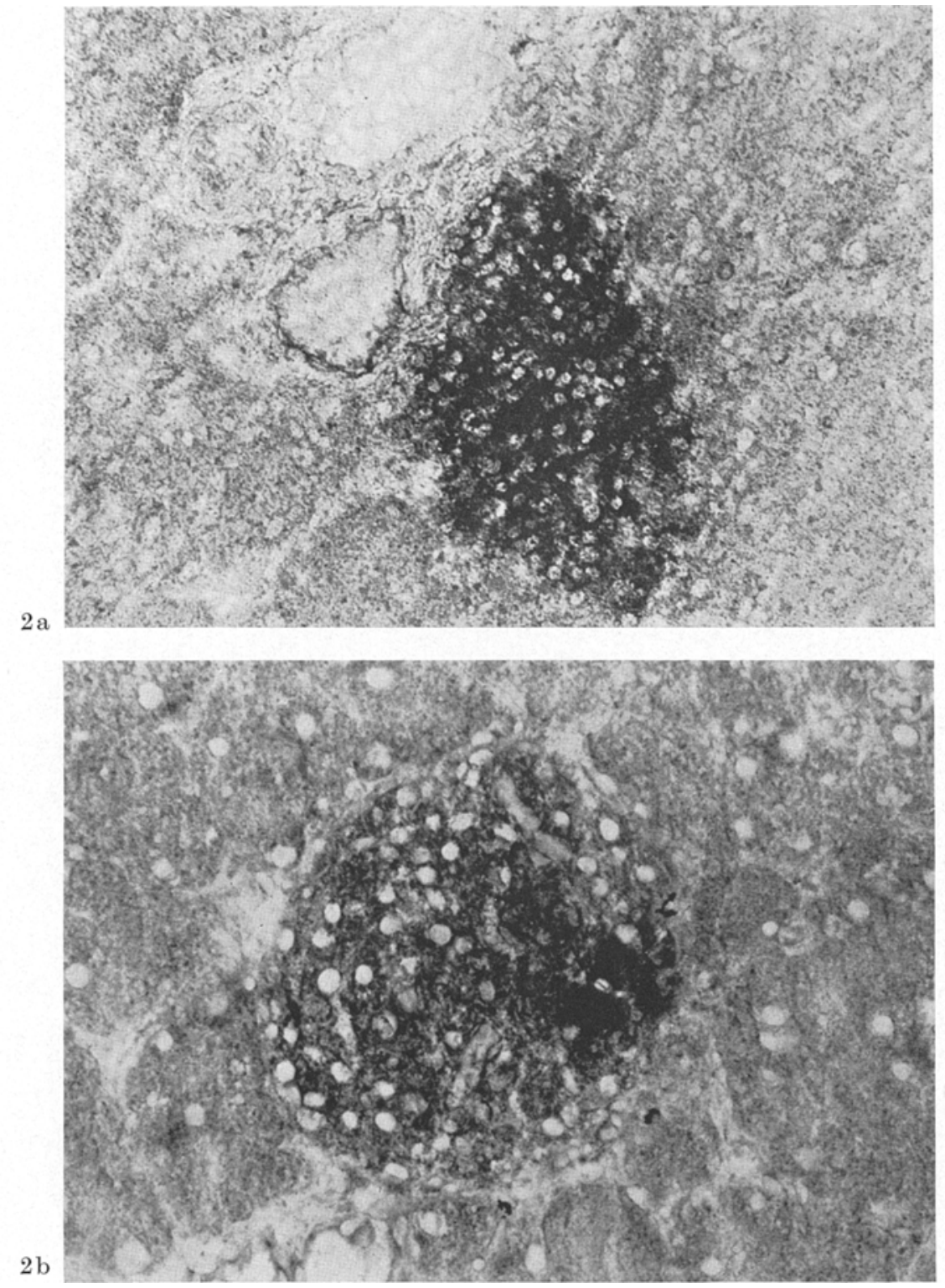

Fig. 2. $\alpha$-Glycerophosphate oxidase activity in the islet cells of mice. a) Very strong activity in controls $(++++)$. $\mathrm{X} 300 . \mathrm{b})$ Moderately strong activity three hours after a single injection of high titre GPAIS $(++)$. X 500

due to the diminished availability of NADH. However, we have no information about this metabolic process. Thus, the changes in GPOX activity only reflect a still unknown metabolic influence on the function of the GPOX during the course of beta cell stimulation.

It is suggested that a possible role of the pentose secretion [37]. Histochemical methods, on the other hand, reveal different changes in G-6-PD activity in hyperglycaemic animals $[17,50]$. In our study no changes in G-6-PD activity were found after treatment with strong anti-insulin serum, while injections of a weak antiserum resulted in a slight reduction. From these data we are unable to contribute anything new 
to the theory concerning the relation between insulin synthesis and the pentose phosphate cycle. Furthermore, it is difficult to interpret the histochemical demonstration of NAD- or NADP-linked dehydrogenases, because these complex reactions always depend on the activity of two enzymes. of these findings it has been suggested that there may be a relation between hormone production and the ACPase activity [48, 50]. However, electronmicroscopically, ACPase is shown to be localized within lysosomes and the Golgi region [30]. Regarding these facts one cannot estimate from the
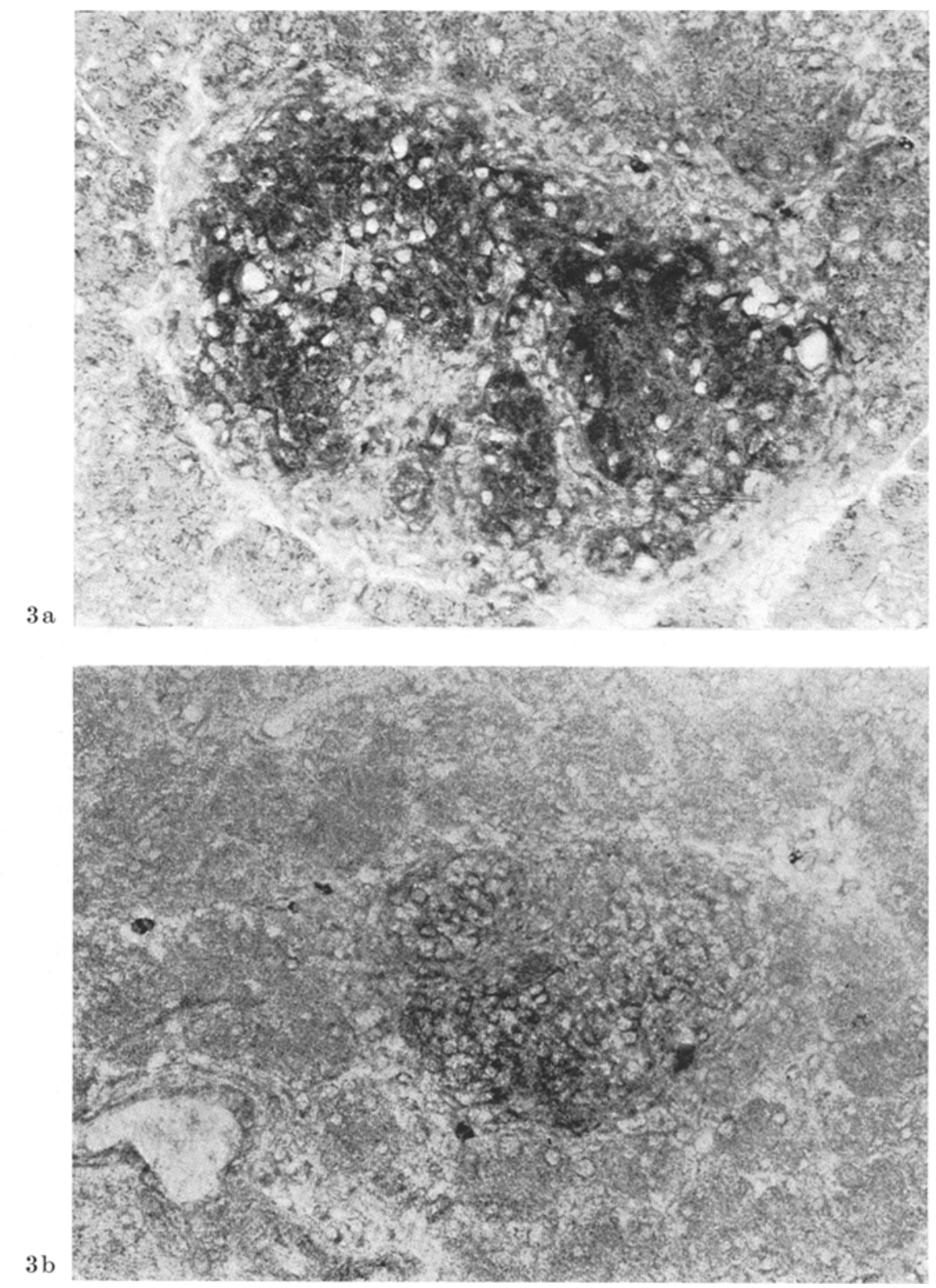

Fig. 3. $\alpha$-Glycerophosphate oxidase activity in the islet cells of mice. X 300. a) Moderately strong activity in mice injected with low titre GPAIS for 7 days $(++)$. b) Slight activity in mice injected with high titre GPAIS for 7 days $(+)$

A slight reduction in ACPase activity is noted after repeated GPAIS injections. Similar changes are observed in older kk-mice [38], in rats with an experimental congenital diabetes $[50]$ and in rabbits with an alloxan diabetes $[20,21]$, whereas the negative results in pancreata of juvenile diabetics [12] are due to the absence of beta cells. On the basis
ACPase activity whether there is a distinct lesion of the beta cell metabolism.

G-6-Pase activity is high in beta cells of many species. In any case it could not be reduced by alloxan or sulphonylureas $[25,26,40]$. Although it is, histochemically, lacking in rat and hamster it can be demonstrated with biochemical methods in these 

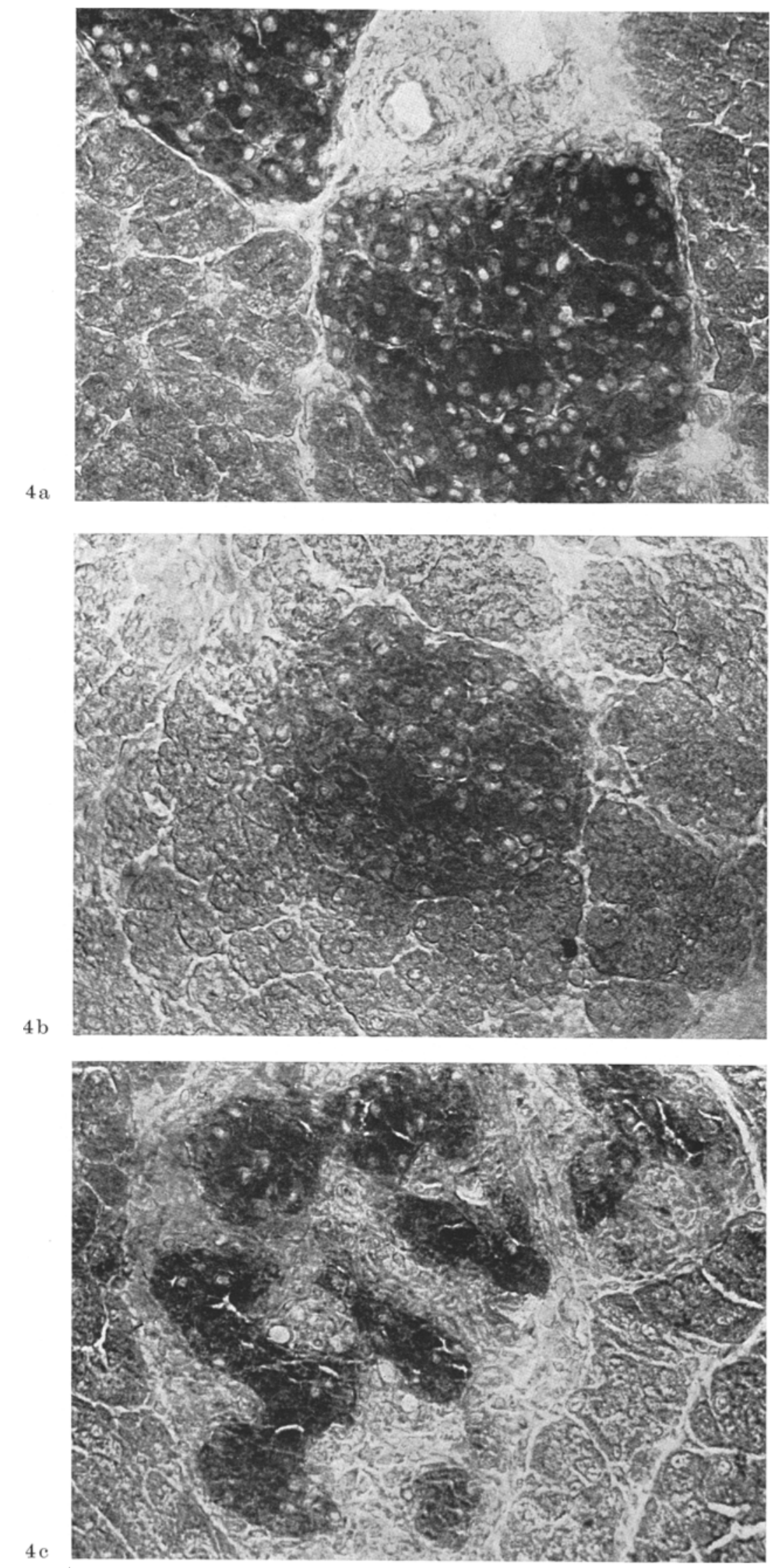

Fig. 4. Glucose-6-phosphate dehydrogenase activity in islet cells of mice. X 300. a) Moderately strong activity in the controls $(++)$. b) Slight activity in mice injected with low titre GPAIS for 7 days $(+)$. c) Moderately strong activity in mice injected with high titre GPAIS for 7 days $(++)$ 

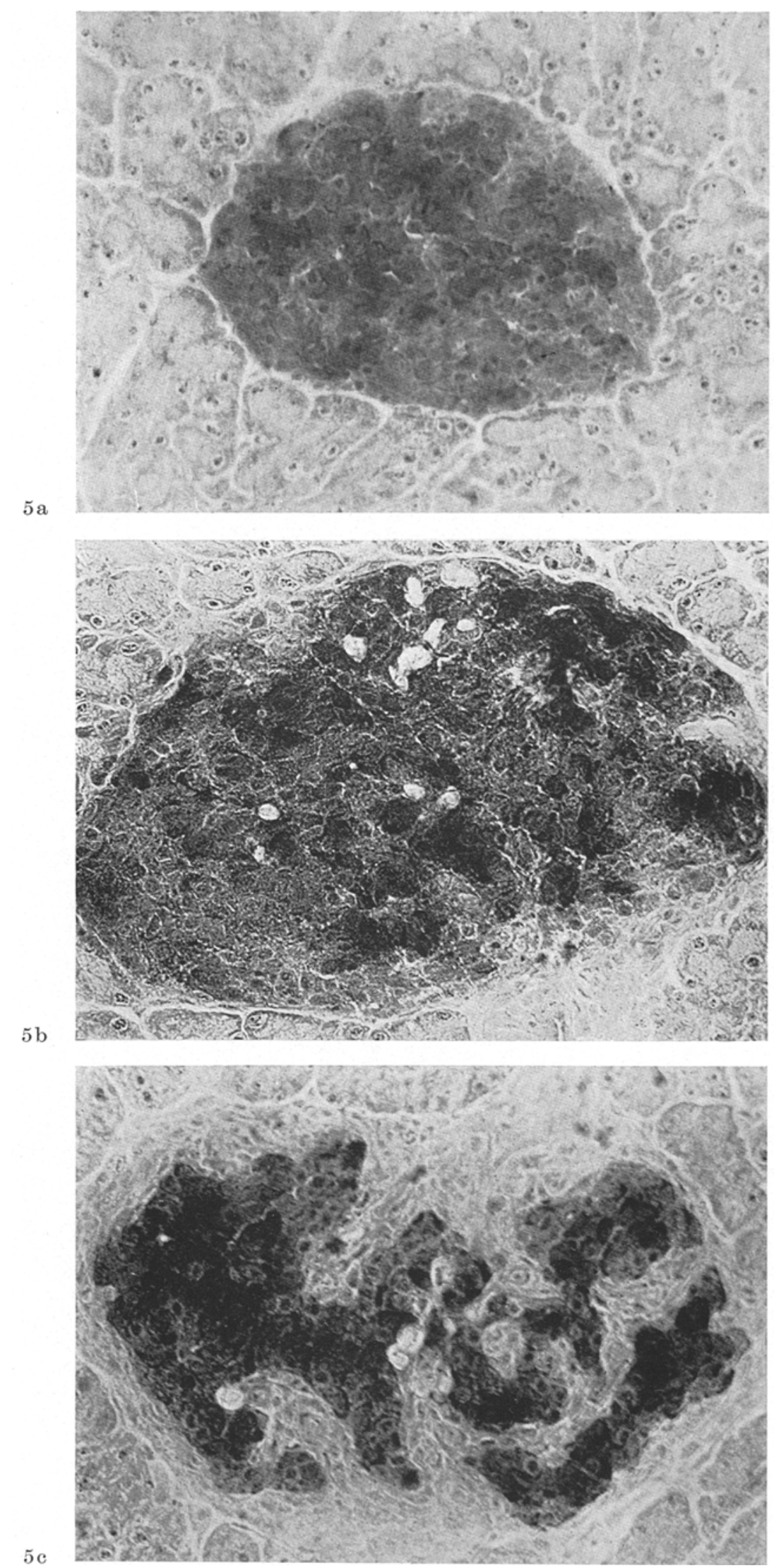

Fig. 5. Glucose-6-phosphatase activity in the islet cells of mice. X 500. a) Strong activity in controls $(+++)$. b) Very strong activity in single beta cells of mice injected with low titre GPAIS for 7 days $(++++)$. c) Very strong activity in nearly all beta cells of mice injected with high titre GPAIS for 7 days $(++++)$ 
species. Depending on the hyperglycaemia, the islets of the mice injected with anti-insulin serum showed a very strong G-6-Pase activity. These findings are in keeping with an increased G-6-Pase activity in cortisone-treated rabbits [11] and obese-hyperglycaemic mice. By means of differential centrifugation G-6-Pase appeared to be localized in the microsome fraction [47] and electronmicroscopically it was found in the endoplasmic retuculum and the nuclear membrane [27]. Regarding these facts it has been suggested that the blood sugar mediated insulin release may be linked to glucose phosphorylation $[24,1]$. Together with a number of other metabolites and enzymes it is thought to play a role in the glucoreceptor system in the beta cells $[15,8,42,44,23,32,36,45,33,34,7]$. But in spite of the strong assumption that glucose phosphorylation is involved in the receptor system, the significance of the marked increase in G-6-Pase activity in the islets of hyperglycaemic animals remains still unclear.

\section{References}

1. Ashcroft, S.J.H., Randle, P.J.: Glucose metabolism and release by pancreatic islets. Lancet 1968 II, 278.

2. - Hedeskov, C.J., Randle, P.J.: Glucose metabolism in mouse pancreatic islets. Biochem. J. 118, 143-154 $(1970)$.

3. - Randle, P.J.: Enzymes of glucose metabolism in normal mouse pancreatic islets. Biochem. J. 119, $5-15(1970)$.

4. Barka, T., Anderson, P.J.: Histochemical methods for acid phosphatase using hexazonium pararosanilin as coupler. J. Histochem. Cytochem. 10, 741-753 (1962).

5. Büchner, Th., Klingenberg, M.: Wege des Wasserstoffs in der lebendigen Organisation. Angew. Chemie 70, 552-570 (1958).

6. Burstone, M.: New histochemical techniques for the demonstration of tissue oxidase (cytochrome oxidase). J. Histochem. Cytochem. 7, 112-122 (1959).

7. Cerasi, E., Luft, R.: Diabetes mellitus - a disorder of cellular information transmission? Horm. Metab. Res. 2, 246-249 (1970).

8. Coore, H.G., Randle, P.J.: Regulation of insulin secretion studied with pieces of rabbit pancreas incubated in vitro. Biochem. J. 93, 66-78 (1964).

9. Freytag, G.: Histologische und autoradiographische Untersuchungen am Inselsystem der Maus bei Insulinantikörperdiabetes. Beitr. path. Anat. 137, 121148 (1968).

10. - Klöppe1, G.: Experimentelle Insulitis und Pankreatitis nach Immunseren gegen Pankreasextrakten ver. schiedener Reinheitsgrade. Beitr. path. Anat. 139, $138-160(1969)$.

11. Gepts, W., Toussaint, D.: In: The structure and metabolism of the pancreatic islets. Brolin, S.E., Hellman, B. and Knutson, H. (Eds.), p. 357. Oxford: Pergamon Press 1964.

12. Gössner, W.: Zur Enzymhistochemie der Langerhansschen Inseln. Verh. dtsch. Ges. Path. 42. Tag. Wien $125-130(1959)$.

13. - Enzymhistochemie der Langerhansschen Inseln. Aus Fortschritte der Diabetesforschung. S. 140. Stuttgart: Georg Thieme 1963.

14. - Die vergleichende Morphologie der Langerhansschen Inseln. Histochemie der Langerhansschen Inseln. Handbuch des Diabetes. Band I, S. 63. München: J.F. Lehmanns 1969.
15. Grodsky, G.M., Batts, A. A., Bennett, L. L., Vcella, C., MoWilliams, N.B., Smith, D.F.: Effects of carbohydrates on secretion of insulin from isolated rat pancreas. Amer. J. Physiol. 205, 638-644 (1963).

16. Hellman, B., Hellerström, C., Larsson, S., Brolin, S.: Histochemical observation on the pancreatic islets in normal and obese-hyperglycemic mice. Z. Zellforsch. $55,235-246$ (1961).

17. - - Oxidative enzymes in the pancreatic islets of normal and obesehyperglycemic mice. $Z$. Zellforsch. 56, 97-106 (1962).

18. - - Histochemical studies on glucose-6-phosphatase, adenosine triphosphatase and amylophosphorylase in the pancreatic islets of normal and obese-hyperglycemic mice. Acta Endocr. (Kbh.). 39, 474-482 (1962).

19. Hess, R., Scarpelli, D.G., Pearse, A.G.E.: The cytochemical localization of oxidative enzymes. II. Pyridine nucleotide-linked dehydrogenases. J. biophys. biochem. Cytol. 4, 753-760 (1958).

20. Thara, N.: Enzyme histochemistry in experimental diabetes mellitus. I. The histochemical findings in the pancreatic islet cells at successive intervals following the administration of diabetogenic substances. Endocr. jap. 12, 215-235 (1965).

21. - Enzyme histochemistry in experimental diabetes mellitus. II. Findings on several enzyme activities in the parenchymal organs, muscular system, intestine and adrenal gland in diabetic rabbits. Endocr. jap. 13, 85-140 (1966).

22. Klöppel, G., Freytag, G., Gutschmidt, G.: Die histologischen Veränderungen des Inselorgans der Maus nach Anti-Schweine-Insulin- und Anti-Rinder-InsulinSerum-Injektionen in Abhängigkeit von Versuchsdauer und Titerhöhe. Acta endocr. (Kbh.) Suppl. 152, $50(1971)$.

23. Lacy, P.E.: The pancreatic beta cell. structure and function. New Engl. J. Med. 276, 187-195 (1967).

24. Lazarus, S.S.: Demonstration of glucose-6-phosphatase in mammalian pancreas. Proc. Soc. exp. Biol. N. Y. 101, 819-822 (1959).

25. - Acid and glucose-6-phosphatase activity of pancreatic B cells after cortisone and sulfonylureas. Proc. Soc. exp. Biol. N. Y. 102, $303-306$ (1959).

26. - Barden, H.: Histochemistry of rabbit pancreatic $B$ cells enzymes and effect of cortisone and alloxan. Fed. Proc. 20, 192 (1961).

27. - Barden, M.S.: Specificity and ultrastructural localisation of pancreatic B cell glucose-6-phosphatase. Diabetes 14, 146-156 (1965).

28. - Bradshaw, M.: Oxidative pathways in pancreatic B cells. Proc. Soc. exp. Biol. N. Y. 102, 463-468 (1959).

29. - Volk, B.W.: The pancreas in human and experimental diabetes. New York: Grune Stratton 1962.

30. - - Barden, H.: Localisation of acid phosphatase activity and secretion mechanism in rabbit pancreatic B cell. J. Histochem. Cytochem. 14, 233-246 (1966).

31. Logothetopoulos, J., Bell, E.G.: Histological and autoradiographic studies of the islets of mice injected with insulin antibody. Diabetes 15, 205-211 (1966).

32. Malaisse, W., Malaisse-Lagae, F., Wright, P.H.: A new method for the measurement in vitro of pancreatic insulin secretion. Endocrinology 80, 99-108 (1967).

33. - Etude de la secretion insulinique in vitro. Bruxelles: Editions Arscia S. A. 1969.

34. Milner, R.D.G., Hales, C.N.: The mechanism of insulin secretion studies through the effects of electrolytes and inhibitors. In: Proceedings of the International Symposium on Early Diabetes (ed. by R. Camerini-Davalos). New York: Academic Press 1970. 
35. Moloney, P.J., Coval, M.: Antigenicity of insulin. Diabetes induced by specific antibodies. Biochem. J. $59,179-185$ (1955).

36. Montague, W., Howell, S.L., Taylor, K.W.: Pentitols and mechanism of insulin release. Nature 215, 10881089 (1967).

37. - Taylor, K.W.: Insulin secretion and the intracellular concentrations of glucose-6-phosphate and 6-phosphogluconate in isolated islets of Langerhans. Biochem. J. 109, $30 \mathrm{P}$ (1968).

38. Nakamura, M., Yamada, K.: Enzymomorphological studies on the pancreatic islets of a diabetic (KK) strain of the mouse. Z. Zellforsch. 66, 396-404 (1965).

39. Pearse, A.G.E.: Histochemistry. Theoretical and applied, 3rd Ed. p. 713. London: J. and A. Churchill, Ltd. 1961.

40. Petkov, P.E., Verne, G., Wegmann, R.: Recherches histoenzymatiques sur le pancreas endocrine au cours du diabète alloxanique chez le rat blanc. Ann. Histochim. 10, 257-274 (1965)

41. - Comparative histochemical studies of mammalian pancreatic islets. The structure and metabolism of the pancreatic islets. Wenner-Gren Symposium No. 16, p. 213. Oxford and New York: Pergamon Press 1970.

42. Samols, E., Marri, G., Marks, V.: Interrelationship of glucagon, insulin and glucose. The insulinogenic effect of glucagon. Diabetes 15, 855-866 (1966).

43. Sasse, D.: Glycogen in der Ontogenese des Verdauungstraktes. - Chemomorphologische und stoffwechselhistochemische Analyse. Ergbn. Anat. Entwickl.-Gesch. 40, 3-66 (1968).
44. Sussman, K.E., Vaughan, G.D., Timmer, R. F.: Factors controlling insulin secretion from the perfused isolated rat pancreas. Diabetes 15, 521 (1966).

45. Sutherland, E.W., Robinson, G.A., Butcher, R.W.: Some aspects of the biological role of adenosine $3^{\prime}, 5^{\prime}$ monophosphate (Cyclic AMP). Circulation 37, 279306 (1968).

46. Taylor, K.W., Montague, W.: The synthesis and release of insulin. Nobel Symposion 13. Pathogenesis of diabetes mellitus (edit.) by E. Cerasi and R. Luft, Stockholm: Almquist and Wiksell. p. 123.

47. Täljedal, J.B.: Presence, induction and possible role of glucose-6-phosphatase in mammalian pancreatic islets. Biochem. J. 114, 387-394 (1969).

48. Vorbrodt, A.: Histochemically demonstrable phosphatases and protein synthesis. Exp. Cell Res. 15, $1-20$ (1958).

49. Wachstein, M., Meisel, E.: Histochemistry of the hepatic phosphatases at physiologic $\mathrm{pH}$ with special reference to the demonstration of bile canaliculi. Amer. J. clin. Path. 27, 13-23 (1957).

50. Yoshikawa, O.: Histochemical studies of various organs in rats with experimental congenital diabetes. Endocr. jap. 16, 609-639 (1969).

Dr. G. Klöppel,

Department of Pathology,

University of Hamburg,

D-2000 Hamburg 20.

Martinistr. 52, Germany 